\title{
PENGARUH EFIKASI DIRI DAN REGULASI DIRI TERHADAP HASIL BELAJAR MATEMATKA SISWA KELAS $X$ SMA ALKHAIRAAT 1 PALU
}

\author{
Aflan Rustam ${ }^{1}$, Dewi Sri Wahyuni \\ ${ }^{1}$ Program Studi Pendidikan Matematika, FKIP, Universitas Alkhairaat \\ aflansenja21@gmail.com \\ ${ }^{2}$ Program Studi Pendidikan Matematika, FKIP. Universitas Alkhairaat \\ dewi031104016@gmail.com
}

\begin{abstract}
ABSTRAK
Jenis penelitian ini adalah ex-post facto yang bersifat kausalitas. Populasi dalam penelitian ini yaitu seluruh siswa kelas X SMA Alkhairaat 1 Palu. Jumlah populasi dalam penelitian ini kurang dari 100, yakni 52 siswa. Olehnya itu pada penelitian ini peneliti tidak melakukan pengambilan sampel, s ehingga penelitian ini merupakan penelitian populasi. Variabel penelitian meliputi efikasi diri $\left(\mathrm{X}_{1}\right)$, regulasi diri $\left(\mathrm{X}_{2}\right)$ yaitu sebagai variabel bebas dan hasil belajar matematika (Y) sebagai variabel terikat. Teknik pengumpulan data menggunakan dokumentasi, tes dan angket. Uji prasyarat menunjukan bahwa data dalam penelitian ini berdistribusi normal, sehingga untuk pengujian hipotesis menggunakan analisis regresi ganda melalui aplikasi SPSS 23. Hasil penelitian ini menunjukan bahwa: 1) tingkat efikasi diri siswa sebesar 71 termasuk dalam kategori sedang. 2) tingkat regulasi diri sis wa sebesar 141 termasuk dalam kategori sedang. 3) tingkat hasil belajar matematika siswa sebesar 63 termasuk dalam kategori sedang. 4) nilai signifikan efikasi diri sebesar $0,000<0,05$ dan koefisien regresi sebesar 0,446 dengan nilai positif, maka $\mathrm{H}_{0}$ ditolak dan $\mathrm{H}_{\mathrm{a}}$ diterima artinya efikasi diri berpengaruh positif terhadap hasil belajar matematika. 4) nilai signifikan regulasi diri sebesar $0,000<0,05$ dan memilki nilai koefisien regresi sebesar 0,264 dengan nilai positif, maka $\mathrm{H}_{0}$ ditolak dan $\mathrm{H}_{\mathrm{a}}$ diterima artinya regulasi diri berpengaruh positif terhadap hasil belajar matematika. 5) koefisien R Square atau koefisien determinasi menunjukan bahwa presentase sumbangan pengaruh variabel bebas sebes ar 58,5\%. Hal ini menunjukan bahwa efikasi diri dan regulasi diri berpengaruh terhadap hasil belajar matematika sebesar 58,5\% dan 41,5\% lainnya dipengaruhi oleh variabel di luar efikasi diri dan regulasi.
\end{abstract}

Kata Kunci : Efikasi diri, Regulasi diri, Hasil belajar

\begin{abstract}
This type of research is ex-post facto which is causal. The population in this study were all students ofclass $X$ at Alkhairaat High School 1 Palu. The population in this study was less than 100, namely 52 students. By this, the researcher did not conduct sampling in this study, so this study was a population research. The research variables included self-efficacy (X1), self-regulation (X2), namely as independent variables and mathematics learning outcomes $(Y)$ as the dependent variable. Data collection techniques using documentation, tests and questionnaires. The prerequisite test shows that the data in this study are normally distributed, so hypothesis testing uses multiple regression analysis through the SPSS 23 application. The results of this study indicate that: 1) the level of self-efficacy of students is 71 in the medium category. 2) the level of self-regulation of students is 141 in the medium category. 3) the level of mathematics learn ing outcomes of students is 63 in the medium category.4) significant value of self-efficacy of 0,000<0,05 and a regression coefficient of 0,446 with a positive value, then $\mathrm{HO}$ is rejected and Ha is accepted meaning selfefficacy has a positive effect on mathematics learning outcomes. 4) significant value of self-regulation of $0,000<0,05$ and has a regression coefficient value of 0,264 with a positive value, then $\mathrm{HO}$ is rejected and
\end{abstract}


Ha is accepted meaning selfregulation has a positive effect on the learning outcomes ofmathematics. 5) $R$ Square coefficient or coefficient of determination shows that the percentage contribution of the influence of independent variables is 58.5\%. This shows that self-efficacy and self-regulation influence the mathematics learning outcomes by $58.5 \%$ and the other $41.5 \%$ are influenced by variables outside ofselfefficacy and regulation.

Keywords : Self-efficacy, Self-regulation, Learning outcomes

\section{PENDAHULUAN}

dalam kehidupan bermasyarakat, berbangsa dan bernegara tidak terlepas dari perkembangan ilmu pengetahuan. Perkembangan ilmu pengetahuan yang semakin pesat telah membawa perubahan dalam dunia pendidikan. Perubahan tersebut memerlukan sumber daya manusia (SDM) yang memiliki pemikiran yang sistematis, logis, kreatif, dan kemampuan untuk bekerja sama agar mampu memperoleh, mengolah dan memanfaatkan informasi untuk bertahan hidup pada keadaan yang selalu berubah dan kompetitif. SDM seperti ini lebih mungkin dihasilkan melalui pendidikan terutama pendidikan formal atau sekolah.

Satu usaha yang dapat dilakukan untuk mencapai tujuan pendidikan tersebut adalah melalui proses pembelajaran di sekolah. Sekolah sebagai lembaga formal, sudah seharusnya mulai menerapkan paradigma baru dalam pendidikan seperti gaya mengajar, pendekatan, strategi, ataupun metode belajar yang lebih afektif. Salah satu masalah pokok dari pembelajaran adalah masi rendahnya kemampuan siswa dalam memahami pelajaran, salah satunya adalah mata pelajaran matematika. Bagi siswa SMP atau SMA, mata pelajaran matematika merupakan salah satu mata pelajaran yang diujikan pada Ujian Akhir Nasional. Begitu pula dalam kehidupan sehari-hari, kemampuan matematis tidak bisa dilepaskan. Oleh karena itu, matematika dianggap memegang peranan yang penting dalam kepentingan akademis (pendidikan formal) maupun dalam kehidupan seharihari.

Matematika berfungsi mengembangkan kemampuan menghitung, mengukur dan menggunakan rumus matematika yang diperlukan dalam kehidupan sehari-hari melalui materi pengukuran dan geometri, serta aljabar dan trigonometri. Matematika juga berfungsi mengembangkan kemampuan mengkomunikasikan gagasan dengan bahasa yang dapat berupa model matematika, kalimat matematika, diagram, grafik atau tabel. Matematika sebagai salah satu ilmu dasar merupakan mata pelajaran yang wajib diajarkan pada semua jenjang pendidikan, baik sekolah dasar, sekolah menengah mupun perguruan tinggi.

Begitu pentingnya peranan matematika seperti yang diuraikan diatas. Namun demikian, Kenyataan yang ada menunjukan hasil belajar siswa pada bidang studi matematika kurang menggembirakan. Tiro menulis dalam makalahnya hasil Trend in International Mathematics and Science Study (TIMSS) dan PISA. Rerata prestasi matematika siswa Indonesia pada TIMSS 1999 adalah 403 berada pada peringkat 34 dari 38 negara peserta. Rerata prestasi matematika siswa Indonesia pada TIMSS 2003 adalah 411 berada pada peringkat 35 dari 46 negara peserta. Kemudian, rerata prestasi matematika siswa Indonesia pada TIMSS 2007 adalah 379 berada pada peringkat 36 dari 49 negara. Dan rerata prestasi matematika siswa Indonesia pada PISA 2000 adalah 367 berada pada peringkat 39 dari 41 negara peserta. Rerata prestasi matematika siswa Indonesia pada 2003 adalah 360 berada pada peringkat 38 dari 40 negara peserta. Rerata prestasi belajar matematika siswa Indonesia pada PISA 2006 adalah 391 berada pada peringkat 50 dari 57 negara peserta, (Ilhamsyah, 2012).

Rendahnya hasil belajar matematika siswa, dipengaruhi oleh banyak faktor. Salah-satu faktor penyebabnya adalah dari dalam diri siswa yaitu mengalami masalah dalam mempelajari matematika. Selain itu 
bisa juga karena faktor lingkungan yang tidak mendukung siswa untuk belajar matematika secara maksimal. Menurut Muhibbin Syah (2006) secara garis besar faktor-faktor yang mempengaruhi hasil belajar dapat dibedakan menjadi tiga macam, yakni: (1) Faktor internal (faktor dari dalam diri siswa), yakni keadaan/kondisi jasmani dan rohani siswa. (2) Faktor eksternal (faktor dari luar siswa), yakni kondisi lingkungan di sekitar siswa. (3) Faktor pendekatan belajar (approach to learning), yakni jenis upaya belajar siswa yang meliputi strategi dan metode yang digunakan siswa untuk melakukan kegiatan pembelajaran materi-materi pelajaran.

Salah satu faktor internal yang penting adalah seberapa besar para siswa yakin bahwa dengan kemampuan yang dimiliki, mereka dapat meraih hasil yang maksimal. Keyakinan seperti ini disebut sebagai efikasi diri. Efikasi diri merupakan salah satu aspek pengetahuan tentang diri atau self knowwledge yang paling berpengaruh dalam kehidupan manusia sehari-hari. Hal ini disebabkan efikasi diri yang dimiliki ikut memengaruhi individu dalam menentukan tindakan yang akan dilakukan untuk mencapai suatu tujuan termasuk di dalamnya perkiraan berbagai kejadian yang akan dihadapi. Siswa yang dikatakan pandai atau memiliki IQ di atas rata-rata belum tentu dapat mencapai prestasi akademik yang tinggi. Kadang siswa menunda untuk mengerjakan tugas atau bahkan berhenti setelah menemukan hambatan dalam proses pengerjaan tugasnya. Salah satu sebabnya adalah kurang adanya keyakinan akan kemampuan dirinya untuk dapat melalui hambatan dan rintangan selama proses belajarnya, sehingga hasil dari proses belajar tersebut tidak optimal. Sebaliknya, jika siswa memiliki keyakinan bahwa dirinya mampu untuk menyelesaikan berbagai tugas dalam proses belajarnya maka siswa tersebut dapat mencapai prestasi yang baik pula. Siswa yang memiliki efikasi diri yang tinggi akan berusaha dengan berbagai cara untuk meraih prestasi yang diinginkan. Mereka tidak mudah putus asa dalam menghadapi hambatan yang dijumpai dalam belajarnya. Siswa yang memiliki efikasi diri yang tinggi akan merasa senang ketika mengikuti pelajaran matematika meskipun terasa sulit, dan akan lebih berusaha untuk menyelesaikan berbagai tugas yang diberikan sehingga dapat meraih prestasi yang tinggi pula. Sedangkan siswa yang efikasi dirinya rendah akan cenderung cepat menyerah ketika menemui kesulitan dalam mengerjakan tugas dan merasa tidak mampu untuk mengerjakan tugas tersebut dengan baik sehingga hasil yang diperolehnya kurang optimal.

$$
\text { Bandura (Pratama, }
$$

mengemukakan bahwa siswa yang memiliki kemampuan matematika beragam, didapatkan hasil bahwa efikasi diri lebih tepat untuk memprediksi prestasi dalam pelajaran matematika dibandingkan dengan kemampuan matematika yang sebenarnya. Penelitian ini menyimpulkan bahwa siswa yang berprestasi kurang bagus kemungkinan disebabkan oleh kurangnya kemampuan yang dimiliki atau karena siswa memiliki kemampuan namun kurang memiliki efikasi diri untuk mengoptimalkan kemampuannya tersebut. Dengan adanya kemampuan efikasi diri siswa akan mempunyai kekuatan untuk menghadapi berbagai tugas perkembangan yang harus diselesaikan dengan sempurna termasuk pencapaian hasil belajarnya. Dari fenomena ini penulis melihat bahwa peranan strategi belajar dan juga keyakinan yang mendorong siswa untuk mencapai hasil belajar sangatlah menunjang untuk hasil yang akan ia dapatkan. Kondisi demikian akan berpengaruh pada pencapaian hasil belajar siswa jika tidak ada pengaturan diri yang baik untuk menyeimbangkan antara kegiatan akademik dengan kegiatan lainnya (regulasi diri), serta keyakinan akan kemampuan diri siswa (efikasi diri) untuk menyelesaikan tugas-tugas. Menurut Bandura (Pratama, 2013) individu dengan efikasi diri yang tinggi cenderung lebih mengupayakan regulasi diri dalam belajar sehingga lebih mampu bertahan dan memperoleh nilai yang lebih baik. Dari pendapat tersebut bisa disimpulkan bahwa ada keterkaitan antara efikasi diri dan regulasi diri untuk mendaptkan hasil belajar yang baik.

Zimmerman mengemukakan bahwa dalam belajar matematika. Suatu strategi belajar yang sangat penting peranannya dan 
ada hubungannya dengan hasil belajar adalah regulasi diri (Purdie, Hattie \&Douglas, 1996). Regulasi diri berkaitan dengan bagaimana individu mengaktualisasikan dirinyan dengan menampilkan serangkaian tindakan yang ditujukan pada pencapaian target. Menurut Bandura (Anfaldi, 2013) Regulasi diri merupakan kemampuan mengatur tingkalahku dan menjalankan tingkahlaku tersebut sebagai strategi yang berpengaruh terhadap perfomansi seseorang mencapai tujuan atau prestasi sebagai bukti peningkatan. hal inilah yang membuat regulasi diri dianggap penting, karena siswa yang memiliki regulasi diri akan secara aktif dalam melakukan aktifitas belajarnya (Wolters, dalam Anfaldi, 2013). Dengan demikian, agar dapat mencapai hasil belajar matematika yang optimal sebaiknya dilakukan sendiri oleh siswa dengan menerapkan strategi regulasi dalam belajarnya.

Hal tersebut didukung oleh berbagai hasil penelitian Zimmerman-Pons (Ilhamsyah, 2012) yang meneliti mengenai regulasi diri. Penelitian ini dilakukan dengan mengkorelasikan antara regulasi diri dengan prestasi belajar matematika dan bahasa inggris siswa sekolah menengah atas. Penelitian ini menemukan bahwa sebagai faktor tunggal regulasi diri memberikan sumbangan efektif hampir mencapai 70 persen bagi prestasi belajar siswa.

Berdasarkan teori-teori yang dikemukakan oleh para pakar di atas bisa disimpulkan bahwa efikasi diri dan regulasi diri berpengaruh terhadap hasil belajar siswa. Oleh karena itu peneliti tertarik untuk meneliti seberapa besar pengaruh efikasi diri dan regulasi diri terhadap hasil belajar matematika siswa Kelas X SMA Alkhairaat 1 Palu.

\section{METODE PENELITIAN}

Pada penelitian ini menggunakan penelitian dengan metode kuantitatif. Metode penelitian kuantitatif dapat diartikan sebagai metode penelitian yang berlandaskan pada filsafat positivisme, digunakan untuk meneliti pada populasi atau sampel tertentu. Populasi dalam penelitian ini adalah seluruh iswa kelas $\mathrm{X}$ SMA
Alkhairaat 1 Palu, tahun pelajaran 2018/2019. Berdasarkan data yang diperoleh dari SMA Alkhairaat 1 Palu jumlah siswa kelas X SMA Alkhairaat 1 Palu adalah 52 siswa. Berdasarkan data tersebut kita mengacu pada pendapat arikunto yang menyatakan bahwa apabila populasinya kurang dari 100, lebih baik diambil semua sehingga penelitiannya merupakan penelitian populasi, selanjutnya jika jumlah pupolasinya lebih dari 100 maka dapat diambil antara $10-15 \%$ atau $20-25 \%$ atau lebih (Sarjun, 2014). Berdasarkan pendapat tersebut maka populasi dalam penelitian ini diambil semuanya sehingga penelitian ini merupakan penelitian populasi.

Pengumpulan data dilakukan dengan instrument yang berbentuk angket dan tes hasil belajar kepada siswa yang merupakan sampel penelitian. Pengumpulan data ini dilakukan oleh peneliti dan sesuai dengan waktu yang telah disepakati antara peneliti dengan pihak sekolah. Selanjutnya kriteria yang digunakan untuk melihat sejauh mana tingkat efikasi diri, regulasi diri, dan hasil belajar matematika siswa adalah sebagai berikut:

1. Efikasi Diri

$\begin{array}{ll}28 \leq \mathrm{ED}<45 & \text { Sangat Rendah } \\ 45 \leq \mathrm{ED}<62 & \text { Rendah } \\ 62 \leq \mathrm{ED}<79 & \text { Sedang } \\ 79 \leq \mathrm{ED}<96 & \text { Tinggi } \\ 96 \leq \mathrm{ED} \leq 112 & \text { Sangat Tinggi }\end{array}$

2. Regulasi Diri
$51 \leq \mathrm{RD}<81$
Sangat Rendah
$81 \leq \mathrm{RD}<112$
Rendah
$112 \leq \mathrm{RD}<143 \quad$ Sedang
$143 \leq \mathrm{RD}<174 \quad$ Tinggi
$174 \leq \mathrm{RD} \leq 204 \quad$ Sangat Tinggi

3. Hasil Belajar Matematika

$0 \leq \mathrm{HBM}<40 \quad$ Sangat Rendah

$40 \leq \mathrm{HBM}<60 \quad$ Rendah

$60 \leq \mathrm{HBM} \leq 75 \quad$ Sedang

$75 \leq \mathrm{HBM}<90 \quad$ Tinggi

$90 \leq \mathrm{HBM} \leq 100$ Sangat Tinggi

Data yang terkumpul dari penelitian selanjutnya akan di olah dengan analisis statistik yaitu analisis deskriptif. Analisis deskriptif dimaksudkan untuk untuk mendeskripsikan suatu data secara statistik. 
Untuk mengetahui sejauh mana kebenaran hipotesis yang telah diajukan maka dilakukanlah pengujian hipotesis, dan untuk menguji hipotesis peneliti menggunakan analisi regresi ganda melalui SPSS 23 dengan taraf signifikansi 5\% ( $\alpha=$ 0,05 ). Adapun rumus analisis regresi ganda sebagai berikut:

$Y=a+b_{1} X_{1}+b_{2} X_{2}$

Keterangan :

$Y=$ Variabel Terikat (nilai yang diduga)

$X_{1}, X_{2}=$ Variabel Bebas

$a, b_{1}, b_{2}=$ Koefisian Regresi Ganda.

$\mathrm{a}=$ Nilai $\mathrm{Y}$, Apabila $\mathrm{X}_{1}=\mathrm{X}_{2}=0$

$b_{1}=$ Besarnya Kenaikan/Penurunan $\mathrm{Y}$ dalam Satuan, Jika $X_{1}$ Naik/Turun Satu Satuan Dan $X_{2}$ Konstan.

$b_{2}=$ Besarnya Kenaikan/Penurunan Y dalam Satuan, Jika $X_{2}$ Naik/Turun

Satu Satuan Dan $X_{1}$ Konstan.

+ Atau $-=$ Tanda Yang Menunjukan Arah Hubungan Antara Y dan $X_{1}$ atau $X_{2}$.
Sumber: M. Iqbal Hasan (2001).

Untuk mengetahui apakah hipotesis yang diajukan diterima atau ditolak, maka dibuatlah hipotesis statistik yang mana hipotesis statistik ini akan menjadi tolak ukur untuk menerima atau menolak hipotesis yang telah dikemukakan. Adapun hipotesis statistik adalah sebagi berikut:

$H_{0}=$ jika nilai signifikan $>0,05$ atau $t_{\text {hitung }}<$ $\mathrm{t}_{\text {tabel }}$ maka tidak terdapat pengaruh variabel $\mathrm{X}$ terhadap variabel $\mathrm{Y}$.

$H_{a}=$ jika nilai signifikan $<0,05$ atau $t_{\text {hitung }}$ $>t_{\text {tabel }}$ maka terdapat pengaruh variabel $\mathrm{X}$ terhadap variabel $\mathrm{Y}$.

\section{HASIL DAN PEMBAHASAN}

Seperti yang telah dikatakan sebelumya bahwa analisis deskriptif dimaksudkan untuk untuk mendeskripsikan suatu data secara statistik. Adapun deskripsi hasil penelitian adalah sebagai berikut:

\section{Efikasi Diri}

Tabel 1. Statistik Deskriptif Efikasi Diri Siswa.

\begin{tabular}{cc}
\hline Statistik & Nilai Statistik \\
\hline Mean & 71 \\
Standar Deviasi & 10 \\
Variansi & 103 \\
Minimum & 50 \\
Maximum & 96 \\
\hline
\end{tabular}

Berdasarkan tabel 1 bisa kita lihat bahwa bahwa skor rata-rata efikasi diri siswa adalah 71, standar deviasi 10 , variansi 103 , skor minimum 50 , dan skor maximum 96 Dari penjelasan tersebut maka bisa kita simpulkan bahwa efikasi diri siswa berada pada kategori sedang.

Tabel 2. Statistik Deskriptif Regulasi Diri Siswa.

\begin{tabular}{cc}
\hline Statistik & Nilai Statis tik \\
\hline Mean & 141 \\
Standar Deviasi & 20 \\
Variansi & 420 \\
Minimum & 102 \\
Maximum & 190 \\
\hline
\end{tabular}

Berdasarkan tabel 2 bisa kita lihat bahwa bahwa skor rata-rata efikasi diri siswa adalah 141, standar deviasi 20, variansi 420 , skor minimum 102 , dan skor maximum 190 Dari penjelasan tersebut maka bisa kita simpulkan bahwa regulasi diri siswa berada pada kategori sedang.

3. Hasil Belajar Matematka 
Tabel 3. Statistik Deskriptif Regulasi Diri Siswa.

\begin{tabular}{cc}
\hline Statistik & Nilai Statis tik \\
\hline Mean & 63 \\
Standar Deviasi & 11 \\
Variansi & 119 \\
Minimum & 42 \\
Maximum & 83 \\
\hline
\end{tabular}

Berdasarkan tabel 3 bisa kita lihat bahwa bahwa skor rata-rata efikasi diri siswa adalah 63, standar deviasi 11, variansi 119 , skor minimum 42 , dan skor maximum 83 Dari penjelasan tersebut maka bisa kita simpulkan bahwa hasil belajar matematika siswa berada pada kategori sedang.

Untuk menguji hipotesis dengan menggunakan analisis regresi ganda maka datanya harus berdistribusi normal, olehnya dilakukanlah uji normalitas yakni untuk mengetahui data yang kita peroleh berdistribusi normal atau tidak. Uji normalitas dalam penelitian ini menggunakan taraf signifikansi $5 \%$ atau 0,05 dan untuk mengetahui datanya berdistribusi normal atau tidak, maka peneliti menggunakan acuan sebagai berikut:

$H_{0}=$ angka signifikan $(\mathrm{Sig})<0,05$, maka data tidak berdistribusi normal.

$H_{a}=$ angka signifikan $(\mathrm{Sig})>0,05$, maka data berdistribusi normal.

Setelah dilakukam uji normalitas maka didapatkan nilai signifikansi sebesar 0,200 . Bisa kita lihat bahwa $0,200>0,05$, maka data dalam penelitian ini berdistribusi normal.

Hipotesis dalam penelitian ini adalah: 1) efikasi diri berpengaruh positif terhadap hasil belajar matematika siswa kelas X SMA Alkhairaat 1 Palu, dan 2) regulasi diri berpengaruh positif terhadap hasil belajar matematika siswa kelas X SMA Alkhairaat 1 Palu. Seperti yang telah dikemukakan sebelumnya bahwa untuk menguji hipotesis yang telah diajukan, peneliti menggunakan analisis regresi ganda. Analisis regresi ganda bertujuan untuk mengetahui ada atau tidaknya pengaruh dua atau lebih variabel bebas $(\mathrm{X})$ terhadap variabel terikat $(\mathrm{Y})$.

Berdasarkan hasil uji regresi ganda, diperoleh persamaan regresi sebagai berikut:

$$
\begin{aligned}
& Y=-6,378+0,446 X_{1}+0,265 X_{2} \\
& \quad \begin{array}{l}
\text { Rumus diatas dapat dijelaskan } \\
\text { sebagai berikut: }
\end{array}
\end{aligned}
$$

1. Nilai konstanta sebesar $-6,378$ artinya jika efikasi diri dan regulasi diri tidak ada, maka hasil belajar matematika siswa sebesar $-6,378$.

2. Nilai koefisien efikasi diri sebesar 0,446 dengan nilai positif. Hal ini berarti bahwa setiap peningkatan satu satuan efikasi diri, maka hasil belajar matematika siswa akan meningkat sebesar 0,446 dengan asumsi bahwa regulasi diri tetap.

3. Nilai koefisien regulasi diri sebesar 0,265 dengan nilai positif. Hal ini berarti bahwa setiap peningkatan satu satuan regulasi diri, maka hasil belajar matematika siswa akan meningkat sebesar 0,265 dengan asumsi bahwa efikasi diri tetap.

Kekuatan hubungan yang terjadi diantara masing-masing variabel bebas Terhadap variabel terikat adalah sebagai berikut:

1. Berdasarkan hipotesis pertama yang diajukan oleh peneliti menunjukan bahwa efikasi diri berpengaruh positif terhadap hasil belajar matematika siswa. Dijelaskan pula dalam hasil analisis regresi berganda bahwa variabel efikasi diri mempunyai nilai sig-t sebesar 0,000 lebih kecil dari taraf signifikansi 0,05 dan $\mathrm{t}_{\text {hitung }}$ mempunyai nilai sebesar 3,876 lebih besar dari nilai $t_{\text {tabel }} 2,016$. Oleh karena itu dapat disimpulkan bahwa $H_{0}$ ditolak dan $H_{a}$ diterima atau dengan kata lain hipotesis pertama diterima. 
2. Berdasarkan hipotesis kedua yang diajukan oleh peneliti menunjukan bahwa regulasi diri berpengaruh positif terhadap hasil belajar matematika siswa. Dijelaskan dalam hasil analisis regresi berganda bahwa variabel regulasi diri mempunyai nilai sig-t sebesar 0,000 lebih kecil dari taraf signifikansi 0,05 dan $t_{\text {hitung }}$ mempunyai nilai sebesar 4,644 lebih besar dari nilai $t_{\text {tabel }} 2,016$. Oleh karena itu dapat disimpulkan bahwa $H_{0}$ ditolak dan $H_{a}$ diterima atau dengan kata lain hipotesis diterima.

Dalam hasil pengujian juga menunjukan bahwa efikasi diri dan regulasi diri memiliki nilai R Square sebesar 0,585. $\mathrm{R}$ Square atau koefisien determinasi yang menunjukan pengaruh langsung variabel $\mathrm{X}_{1}$ dan $\mathrm{X}_{2}$ terhadap variabel $\mathrm{Y}$ yang dinyatakan dalam persentase. Koefisien determinasi adalah 0,585 berarti bahwa variabel $\mathrm{X}_{1}$ dan $\mathrm{X}_{2}$ mempengaruhi secara langsung variabel Y sebesar 58,5\% sedangkan $(100-58,5) \%$ $=41,5 \%$ dipengaruhi oleh faktor lain di luar variabel $X_{1}$ dan $X_{2}$. Dari penjelasan tersebut bisa kita simpulkan bahwa efikasi diri dan regulasi mempengaruhi hasil belajar matematika siswa sebesar 58,5\% sedangkan 41,5\% lainnya dipengaruhi oleh faktor lain di luar variabel $X_{1}$ dan $X_{2}$.

\section{KESIMPULAN}

Berdasarkan hasil penelitian dan pembahasan, maka peneliti dapat membuat kesimpulan sebagai berikut:

1. Gambaran efikasi diri siswa kelas $\mathrm{X}$ SMA Alkhairaat 1 Palu sebagaimana hasil analisis deskriptif bahwa siswa yang berada pada kategori sangat rendah sebanyak $0 \%$, kategori rendah sebanyak $17 \%$, kategori sedang sebanyak 59\%, kategori tinggi sebanyak 22\%, dan kategori sangat tinggi sebanyak $2 \%$. Dalam hasil analisis deskriptif juga menunjukan bahwa efikasi diri memperoleh skor rata-rata $=71$, std. Deviasi $=10$, variansi $=102$, skor minimum $=50$, dan skor maximum $=96$. Berdasarkan kriteria pengklasifikasian pada BAB III, maka dapat disimpulkan bahwa efikasi diri siswa kelas X SMA Alkhairaat 1 Palu berada pada kategori Sedang. Pada hasil pengujian hipotesis menunjukan bahwa efikasi diri memiliki nilai koefisien regresi sebesar 0,446 dengan nilai positif, nilai $t_{\text {hitung }}=3,876>$ $\mathrm{t}_{\text {tabel }}=2,016$; dan nilai signifikan $=0,000$ lebih kecil dari 0,05. Sehingga dapat disimpulkan bahwa efikasi diri berpengaruh positif terhadap hasil belajar matematika siswa kelas X SMA Alkhairaat 1 Palu.

2. Gambaran regulasi diri siswa SMA Alkhairaat 1 Palu sebagaimana hasil analisis deskriptif bahwa siswa yang berada pada kategori sangat rendah sebesar 0\%, kategori rendah sebanyak $7 \%$, kategori sedang sebanyak $46 \%$, kategori tinggi sebanyak 39\%, dan kategori sangat tinggi sebanyak $0 \%$. Dalam hasil analisis deskriptif juga menunjukan bahwa regulasi diri memiliki skor rata-rata $=141$, std. Desviasi $=20$, variansi $=420$, skor minimum $=102$, dan skor maximum $=$ 190. Berdasarkan kriteria pengklasifikasian pada BAB III, maka dapat disimpulkan bahwa regulasi diri siswa kelas X SMA Alkhairaat 1 Palu berada pada kategori sedang. Pada hasil pengujian hipotesis menunjukan bahwa regulasi diri memiliki nilai koefisien regresi sebesar 0,265 dengan nilai positif, nilai $t_{\text {hitung }}=4,644>t_{\text {tabel }}=2,016$ dengan nilai signifikan $=0,000$ lebih kecil dari 0,05 . Sehingga dapat disimpulkan bahwa regulasi diri berpengaruh positif terhadap hasil belajar matematika siswa kelas $\mathrm{X}$ SMA Alkhairaat 1 Palu.

3. Gambaran hasil belajar matematika siswa kelas X SMA Alkhairaat 1 Palu sebagai mana hasil analisis deskriptif bahwa siswa yang berada pada kategori sangat rendah sebanyak sebanyak $0 \%$, kategori rendah sebesar $46 \%$, kategori sedang sebanyak $28 \%$, kategori tinggi sebesar 26\%, dan kategori sangat tinggi sebanyak $0 \%$. Dalam hasil analisis deskripsi juga menunjukan bahwa hasil belajar matematika memiliki skor ratarata $=63$, std. deviasi $=11$, variansi $=$ 119 , skor minimum $=42$, dan skor maximum $=83$. Berdasarkan kriteria pengklasifikasian hasil belajar matematika pada BAB III, maka dapat disimpulkan bahwa hasil belajar 
matematika siswa kelas $\mathrm{X}$ SMA Alkhairaat 1 Palu berada pada kategori sedang.

4. R Square atau koefisien daterminasi yang menunjukan pengaruh langsung variabel $\mathrm{X}_{1}$ dan $\mathrm{X}_{2}$ terhadap variabel $\mathrm{Y}$ yang dinyatakan dalam persentase. Berdasarkan hasil pengujian hipotesis menunjukan bahwa nilai $\mathrm{R}$ Square sebesar 0,585; jika dirubah kedalam bentuk persentase maka $0,585=58,5 \%$ berarti bahwa efikasi diri $\left(\mathrm{X}_{1}\right)$ dan regulasi diri $\left(\mathrm{X}_{2}\right)$ mempengaruhi hasil belajar matematika (Y) siswa kelas $\mathrm{X}$ SMA Alkhairaat 1 Palu sebesar 58,5\% sedangkan $41,5 \%$ lainnya dipengaruhi oleh faktor lain di luar variabel efikasi diri $\left(\mathrm{X}_{1}\right)$ dan regulasi diri $\left(\mathrm{X}_{2}\right)$.

\section{DAFTAR PUSTAKA}

Anfaldi, A. (2013). Regulasi Diri. Diakses pada tanggal 15 Desember 2017. fazrianfaldi.blogspot.com/2013/02/re gulasi-diri.html.
Arikunto, S. (2006). Prosedur Penelitian; Suatu Pendekatan Praktik. Jakarta: Rineka Cipta

Hasan, M.I. (2001). Pokok-pokok Materi STATISTIK 1 (Statistik Deskriptif) Edisi Dua. Jakarta:PT Bumi Aksara.

Ilhamsyah. (2012). Pengaruh efikasi diri, Metakognisi dan Regulasi Diri Terhadap Prestasi Belajar Matematika Siswa Kelas X SMAN di Kabupaten Wajo. Tesis tidak diterbitkan. Makassar: Program Pascasarjana Universitas Negeri Makassar.

Nur, F \& Latif, A.K. (2016). Pengaruh Self Esteem Dan Self Regulation Terhadap Hasil Belajar Matematika Siswa Kelas XI Madrasah Aliyah Guppi Samata Kab. Goa. Jurnal Biotek, Vol. 4, No. 2. Diakses Pada Tanggal 13 Agustus 2018, Dari Journal.uin-

alaudin.ac.id/indeks.php/boitek/Artic le/download/1796/1750.

Pratama, S. (2013). Efikasi Diri. Diakses Pada Tanggal 15 Desember 2017. http://saharpratama.blogspot.co.id/20 13/02/efikasi-diri-self-efficacy.html.

Syah, Muhibbin. (2006). Psikologi Belajar. Jakarta: PT Raja Grafindo Persada. 